\title{
STRATEGI PEMBELAJARAN GURU DALAM MENGELOLA AMARAH SISWA (STUDI KASUS DI KB ANGGREK MUARA BADAK TAHUN AJARAN 2015/2016
}

\author{
Nur Intang \\ PG PAUD, FKIP, Universitas Widya Gama Mahakam Samarinda \\ nurintangpaud15@gmail.com \\ Rizqi Syafrina \\ PG PAUD, FKIP, Universitas Widya Gama Mahakam Samarinda \\ nonon11185@gmail.com \\ ABSTRACT
}

\begin{abstract}
Early children who control their emotions well, in general will be accepted by the environment well too. Conversely, angry students will be very detrimental to other students because a lot of science that should get ignored.by that's why a strategy used by teachers in managing anger of children is very determine the outcome of teaching and learning process. This study aims to find out the Teacher Learning Strategy in Managing Student Angarah Group B in the Anggrek Muara Badak Playing Group of Learning Year 2015/2016. In this study the approach used is qualitative descriptive method approach that is research that intends to understand the phenomenon about what experienced research subjects. The subjects were sixteen students, consisting of five boys and eleven girls. Data collection in this study using observation sheet, Interview Sheet, and Documentation. Data analysis techniques used in this study are Miles and Hiberman techniques that include data collection (data collection); data reduction; presentation of data (data display); and conclusion or verification (conclution drawing \& verifying). From the results of research that has been done revealed that the Teacher Learning Strategy in Managing Student Angarah on Group B in the Clock Play Anggrek Estuary Rhino Year Learning 2015/2016 refers to the three important elements of emotional intelligence; (1) Personal skills (selfmanaging); (2) social skills (dealing with a relationship); (3) social skills (intelligence to arouse the desired response to others). While the cause of students become angry is: (1) because Lack of attention, too mendekti, have a brother who was not far adrift until the pattern of parenting that tends to side with one child. (2) Although there is a single child who is angry but it happens because the parenting pattern of parents who tend to spoil the child too.
\end{abstract}

Keywords : Learning Strategy, Teacher, Student Anger

\section{PENDAHULUAN}

\section{Latar Belakang}

Setiap anak mempunyai suatu keunikan, dan keunikan setiap anak berbeda-beda. Ada anak yang bersifat pendiam, pemarah, sabar, dan sebagainya. Begitu pun dalam mengelola emosi, perilaku anak jelas berbeda-beda. Pengendalian emosi yang bermacammacam itu terbentuk berdasarkan bagaimana cara orang tua membimbing anaknya dalam mengungkapkan perasaan emosinya. Anak usia dini yang mengendalikan emosinya dengan baik, pada umumnya akan diterima oleh lingkungannya dengan baik pula.Sebaliknya, Anak didik yang pemarah akan sangat merugikan peserta didik lainnya karena banyak ilmu pengetahuan yang seharusnya didapatkan menjadi 
terabaikan.oleh karena itulah suatu strategi yang digunakan guru dalam mengelola amarah anak sangat menentukan hasil proses belajar mengajar.

Sesuai dengan pasal 28 UndangUndang, sistem Pendidikan Nasional No. 20/2003 ayat 1 , yang termasuk anak usia dini adalah anak yang masuk dalam rentang usia 0-6 tahun. Sementara itu, menurut kajian rumpun ilmu PAUD dan penyelenggaraannya di beberapa negara, PAUD dilaksanakan sejak usia 0-8 tahun.

Menurut Uno (2008: 3), Strategi pembelajaran adalah cara-cara yang akan digunakan oleh pengajar untuk memilih kegiatan belajar yang akan digunakan selama proses pembelajaran. Pemilihan tersebut dilakukan dengan mempertimbangkan situasi dan kondisi, sumber belajar, kebutuhan dan karakteristik peserta didik yang dihadapi dalam rangka mencapai tujuan pembelajaran tertentu. Sedangkan menurut WinaSanjaya(2008: 126)strategi pembelajaran dapat diartikan sebagai perencanaan yang berisi tentang rangkaian kegiatan yang didesain untuk mencapai tujuan pendidikan tertentu.

Strategi penyampaian isi pembelajaran merupkan komponen variabelmetode untuk melaksanakan proses pembelajaran. Fungsi strategi penyampaian pembelajaran adalah: (1) menyampaikan isi pembelajaran kepada pebelajar,dan (2) menyediakan informasi atau bahan-bahan yang diperlukan pebelajaruntuk menampilkan unjuk kerja.

Konsep dasar strategi belajar mengajar menurut Surya Dharma, (2008:6)meliputi hal-hal: (1) menetapkan spesifikasi dan kualifikasi perubahan perilaku pebelajar; (2) menentukan pilihan berkenaan dengan pendekatan terhadap masalah belajar mengajar, memilih prosedur, metode dan teknik belajar mengajar; dan (3) norma dan kriteria keberhasilan kegiatan belajar mengajar.

Strategi dapat diartikan sebagai suatu garis-garis besar haluan untuk bertindak dalam rangka mencapai sasaran yang telah ditentukan.Dikaitkan dengan belajar mengajar, strategi bisa diartikan sebagai pola-pola umum kegiatan guru, murid dalam perwujudan kegiatan belajar mengajar untuk mencapai tujuan yang telah ditentukan.Menurut Newman dan Mogan dalam Surya Dharma, (2008:7-8) strategi dasardalam konteks pembelajaran adalah sebagai berikut :

1. Mengidentifikasi dan menetapkanspesifikasi dan kualifikasi perubahan tingkah laku kepribadian peserta didikyang diharapkan.

2. Memilih sistem pendekatan belajar mengajar berdasarkanaspirasi dan pandangan hidup masyarakat.

3. memilih dan menetapkanprosedur, metode dan teknik belajar mengajar 
yang dianggap paling tepat,efektif, sehingga dapat dijadikan pegangan oleh para guru dalam menunaikankegiatan mengajarnya; dan

4. Menetapkan norma-norma dan batas minimalkeberhasilan atau kriteria dan standar keberhasilan sehingga dapat dijadikanpedoman oleh guru dalam melakukan evaluasi hasil kegiatan belajar mengajaryang selanjutnya akan dijadikan umpan balik buat penyempurnaan sisteminstruksional yang bersangkutan secara keseluruhan. Sedangkan menurut Elizabet B. Hurlock (1992 : 46-47) bahwa ada sepuluh prinsip-prinsip perkembangan, yaitu sebagai berikut:

1. Prinsip pertama perkembangan adalah perkembangan menyangkut perubahan, tujuan perkembangan adalah realisasi diri atau pencapaian kemampuan bawaan.

2. Prinsip kedua perkembangan adalah bahwa perkembangan awal lebih penting daripada perkembangan selanjutnya, karena dasar awal sangat dipengaruhi oleh proses belajar dan pengalaman. Apabila perkembangan membahayakan penyesuaian pribadi dan sosial anak, ia dapat diubah sebelum menjadi pola kebiasaan.

3. Prinsip ketiga perkembangan menekankan kenyataan bahwa perkembangan timbul dari interaksi kematangan yang menetapkan batas bagi perkembangan.

4. Prinsip keempat perkembangan adalah bahwa pola perkembangan dapat diramalkan, walaupun pola yang dapat diramalkan ini dapat memperlambat atau dipercepat oleh kondisi lingkungan dimasa pralahir dan pascalahir.

5. Prinsip kelima perkembangan adalah bahwa pola perkembangan mempunyai karakteristik tertentu yang dapat diramalkan. Yang terpenting diantaranya ialah adanya persamaan pola perkembangan bagi semua anak; perkembangan berlangsung dari tanggapan umum ketanggapan spesifik, perkembangan terjadi secara berkesinambungan, berbagai bidang berkembangan dengan kecepatan yang berbeda dan terdapat pula korelasi dalam perkembang.

6. Prinsip keenam perkembangan adalah bahwa terhadap perbedaan individu dalam perkembangan yang sebagian karena pengaruh bawaan dan sebagian karena kondisi lingkungan. Ini berlaku baik dalam perkembangan fisik maupun psikologis.

7. Prinsip ketujuh perkembangan adalah terdapat periode dalam pola perkembangan yang disebut periode pralahir, masa neonatus, masa bayi, masa kanak-kanak awal, akhir masa 
kanak-kanak dan masa puber. Dalam semua periode ini terdapat saat-saat keseimbangan dan ketidakseimbangan serta pola perilaku yang normal dan dan terbawa dari periode sebelumnya biasa disebut perilaku "bermasalah".

8. Prinsip kedelapan perkembangan adalah adanya harapan sosial untuk setiap periode perkembangan. Harapan sosial ini berbentuk tugas perkembangan yang memungkinkan para orang tua dan guru mengetahui pada usia berapa anak-anak mampu menguasai berbagai pola perilaku yang diperlukan bagi penyesuaian yang baik.

9. Prinsip kesembilan perkembangan adalah bahwa setiap bidang perkembangan mengandung kemungkinan bahaya baik fisik maupun psikologis yang dapat mengubah pola perkembangan.

10. Prinsip kesepuluh perkembangan adalah bahwa kebahagian bervariasi pada berbagai periode dalam pola perkembangan. Tahun pertama kehidupan biasanya paling bahagia dan masa puber biasanya yang paling tidak bahagia.

Novita Tandry (2011 : 13) mengatakan bahwa "marah adalah normal bagi anak kecil, kemarahan anak mengacu pada reaksinya terhadap situasi atau caranya menunjukkan emosi”. Sedangkan menurut Seto Mulyadi (2004 : 12) "marah merupakan rasa yang sangat manusiawi sehingga tidak dapat disalahkan”. Dapat dipahami bahwa amarah adalah rasa manusiawi yang tidak dapat disalahkan.

Dengan demikian, dari beberapa pendapat di atas penulis menyimpulkan amarah adalah suatu perasaan tidak senang karena diperlakukan tidak sepantasnya dan melakukan sesuatukarena sudah tidak bisa menahan emosinya.

Kecerdasan emosional menuntut diri untuk belajarmengakui dan menghargai perasaan diri sendiri dan orang lain dan untuk menanggapinya dengan tepat, menerapkan dengan efektif energi emosi dalam kehidupan dan pekerjaan seharihari.

Menurut Kemendikbud (2014: 1) Tiga unsur penting kecerdasan emosional terdiri dari:

1. Kecakapan pribadi (mengelola diri sendiri);

2. kecakapan sosial (menangani suatu hubungan);

3. keterampilan sosial (kepandaian menggugah tanggapan yang dikehendaki pada orang lain).

Adapun Strategi Mengorganisasi Pengembangan Kecerdasan Sosial Emosional Anakmenurut Kemendikbud (2014: 7-8) adalah sebagai berikut :

1. Kegiatan mengorganisasikan berdasarkan kebutuhan, minat dan karakteristik perkembangan anak yang 
menjadi sasaran pengembangan kecerdasan emosi.

2. Kegiatan yang diorganisasikan bersifat holistik ( menyeluruh ).

3. Kegiatan diorganisasikan sesuai dengan tuntutan kondisivitas pengembangan kecerdasan emosi, diantaranya dikondisikan dalam suasana kekeluargaan, suasana yang penuh kasih sayang, suasana yang penuh kesejukan dan kedamaian,tetapi tetap dapat menempatkan setiap komponen secara bertanggung jawab atas setiap peran yang dipegangnya.

4. Kegiatan diorganisasikan pada suasana yang dapat memberikan kesempatan kepada anak untuk menyampaikan gagasan-gagasannya, memberikan kesempatan pada anak untuk memberikan masukan dalam pengambilan keputusan.

5. Tugas guru diarahkan untuk membimbing dan memfasilitasi bukan untuk mengatur berbagai prilaku secara otoriter.

6. Peraturan kelas diorganisasikan secara jelas batasbatasnya sehingga tumbuh kesadaran untuk menaatinya secara utuh dan bertanggung jawab.

7. Pembimbingan dan kegiatan memfasilitasi dilakukan dengan penuh kasih sayang sehingga dapat mempersiapkan anak menjadi pribadi dan anggota masyarakat yang sehat dan mampu bersosialisasi dan berkomunikasi.

8. Organisasi kegiatan juga memberikan kesempatan dan menganjurkan agar orang tua dapat berpartisipasi dengan anak-anaknya dalam kegiatan sekolah. Menurut Novita Tandry (2011 :

19)fase kemarahan pada anak yaitu:

1. Pada usia 2 (dua) tahun umumnya kemarahan berkembang sampai ke titik tertinggi. Kemarahan anak bisa berlangsung 5-10 menit karena ia telah membangun kesadaran sebagai individu dan mengetahui kebutuhannya sendiri.

2. Pada usia 5 (lima) tahun seiring bertambahnya usia, umumnya kemarahan anak memiliki durasi lebih pendek (beberapa menit saja).

3. Kemudian pada usia 10 (sepuluh) tahun, yang tersisa adalah letupan kemarahan kecil yang berlangsung beberapa detik.

Terkait dengan hal tersebut diatas, proses pembelajaran harus mengikuti sifat dan karakter anak. Dalam melaksanakan strategi pembelajaran, guru berinteraksi dengan anak secara individual dan dengan kelompok kecil.Semua kegiatan pembelajaran dapat direncanakan oleh guru untuk mengoptimalkan kemampuan dan keterampilan mereka tentang apa yang dapat mereka lakukan sendiri dan keterampilan apa yang perlu 
dikembangkan dengan bantuan guru. Untuk itu strategi pembelajaran guru sangatlah penting dalam menunjang kegiatan yang berlangsung di dalamkelas yang suasananya tidak selalu tenang. Karena dengan- banyaknya karakteristik anak yang unik, tentu juga ada banyak tingkah laku yang ditimbulkan oleb anakanak tersebut.Misalnya saja perasaan marah sering diekspresikan sebagai hal yang wajar dan normal- Kasanya seseorang setelah melampiaskankemarahannya akan menjadi lega dan tenang tetapi perasaan yang secara terus menerus dipendam akan berdampak buruk dan mengganggu aktifitas sehari-hari.

Rasa marah tidak hanya menimpa orang dewasa tetapi- pada semua orang tak terkecuali anak balita atau bayi. Novita Tandry (2011:14) mengemukakan bahwa "karakter marah seorang bayi diyakini $80 \%$ terbentuk sejak masih dalam kandungan, yang disebabkan oleh kegiatan dan respons ibunya atas berbagai kejadian. Sisanya 20\% dipengaruhi dari lingkungan dan pengalaman hidupnya sendiri, yang juga memberikan sentuhan akhir karakter marah seseorang

Fenomena kemarahan anak ini juga terjadi pada beberapa anak didik di $\mathrm{KB}$ Anggrek Muara Badak. Perilaku anak didik tersebut dialami ofeh semua guru yang pernah mengajar di kelas anak didik tersebut.Sikap marah seperti yang diperlihatkan anak didik tersebut juga menimpa beberapa anak didik lainnya. Anak didik yang pemarah ini akan sangat merugikan peserta didik lainnya karena banyak ilmu pengetahuan yang seharusnya dia dapatkan menjadi terabaikan.

Berangkat dari konsep dan fenomena riil di lapangan dengan teori yang ada, maka peneliti merasa tertarik untuk mengungkap suatu strategi yang digunakan guru dalam mengelola amarah, oleh karena itu judul penelitian irri adalah Studi tentang Strategi pendekatan Guru dalam Mengelola Amarah Anak Pada Kelompok B di KB Anggrek Muara Badaktahun Pembelajaran 2015/2016.

\section{METODOLOGI PENELITIAN}

\section{Desain Penelitian}

Desain penelitian yang digunakan dalam penelitian ini adalah metode deskriptif kualitatif yang diartikan sebagai penelitian yang bermaksud untuk memahami fenomena tentang apa yang dialami subjek penelitian secara menyeluruh yang menghasilkan data deskriptif berupa kata-kata atau lisan (Moleong, 2010:6). Lebih lanjut Bogdan dan Taylor dalam (Moleong, 2010:9 ) mendefinisikan penelitian kualitatif sebagai penelitian yang menghasilkan data deskriptif berupa kata-kata tertulis atau lisan dari orang orang dan perilaku yang dapat diamati. Menurut tahap penjelasannya, penelitian pelaksanaan 
membelajaran diKB Anggrek Muara

Badak bersifat deskriptif.Peneliti menggunakan tipe deskriptif karenapeneliti mencoba menggambarkan secara mendalam tentang pelaksanaanpembelajaran di Kelompok Bermain tersebut. Pada tipe ini peneliti melaksanakanobservasi, wawancara dan studi dokumentasi mendalam terhadap subjekpenelitian dengan tujuan memperoleh informasi serta bentuk pelaksanaan Pembelajarannya.

\section{Subjek Penelitian}

Subjek penelitian adalah anak usia dini kelompok B di KB Anggrek Muara Badak Kutai Kartanegara Tahun Pelajaran 2015/2016 yang berjumlah 16 siswa, terdiri dari 5 anak laki-laki dan 11 anak perempuan.

\section{Waktu dan Tempat Penelitian}

Penelitian ini di laksanakan pada bulan September 2015 di kelompok B1 di KB Anggrek Muara Badak Kutai Kartanegara Tahun Pelajaran 2015/2016 dengan waktu pelaksanaaan yang fleksibel.

\section{Instrumen Penelitian}

Menurut Suharsimi Arikunto (2010: 101) instrumen penelitian adalah alat bantu yang dipilih dan digunakan peneliti untuk mempermudah dalam mengumpulkan data agar kegiatan tersebut menjadi sistematis. Instrumen yang digunakan dalam penelitian ini adalah lembar observasi ( lihat lampiran 1),
Interview ( lihat lampiran 2 ) dan

Dokumentasi. Menurut Peraturan Pemerintah Pendidikan Nasional Republik Indonesia Nomor 58 Tahun 2009 ada beberapa hal mengenai Standar Proses Pendidikan Dini yang akan dijadikan indikator di dalam penelitian ini.

Menurut Seto Mulyadi (2004 : 27) ada beberapa hal yang dapat menyebabkan anak mengalami marah, Hal tersebut akan menjadi indikator di dalam penelitian ini. Adapun indikator-indikatornya yaitu sebagai berikut:

a. Janji yang tidak ditepati.

b. Kurang perhatian.

c. Dipaksa disiplin.

d. Cemburu pada saudara.

e. Orang tua terlalu mendikte.

f. Tak mampu menyesuaikan diri dengan perubahan.

Semua indikator tersebut telah menjadi pedoman bagi peneliti untuk menjadi kisi-kisi dalam membuat pedoman wawancara. Dari indikator tersebut dibuat kisi-kisi dengan dikembangkan sesuai dengan tujuan penelitian yaitu untuk mengetahui strategi pembelajaran guru dalam mengelola amarah anak kelompok B1 di KB Anggrek Muara Badak, Kutai Kartanegara Tahun Pelajaran 2015/2016.

\section{Teknik Pengumpulan Data}

Dalam penelitian ini digunakan interview sebagai teknik pengumpulan data yang utama dan observasi serta 
dokumentasi sebagai pendukung teknik pengumpulan data. Untuk itu akan dijelaskan lebih rinci mengenai teknikteknik dalam pengumpulan data, yaitu : 1) Observasi, 2) Interview, 3) Dokumentasi.

\section{Teknik Analisis Data}

Dalam penelitian ini analisis yang dilakukan peneliti adalah bertujuan melakukan abstraksi setelah rekaman fenomena-fenomena khusus dikelompokkan menjadi satu. Setelah dilakukan pengumpulan data, tahap selanjutnya adalah pengolahan dan analisis data.

Menurut Miles dan Hiberman dalam Sugiyono( 2010: 246-247) teknikanalisa data meliputi: pengumpulan data (data collection); reduksi data (data reduction); penyajian data (data display); dan kesimpulan atau verifikasi(conclution drawing \& verifying).

\section{Pemeriksaan atau Pengecekan}

\section{Keabsahan Data (Triangulasi)}

Moleong (2010: 330) mengungkapkan bahwa triangulasi data adalah teknik pemeriksaan keabsahan data yang memanfaatkan sesuatu diluar data tersebut untuk keperluan pengecekan data atau sebagai pembanding terhadap data tersebut. menurut Moleong (2010: 331), tekhnik triangulasi yang paling banyak digunakan ialah pemeriksaan melalui sumber data dan instrumen. Hal ini dapat dicapai dengan cara: 1) Membandingkan data hasil pengamatan dengan data hasil wawancara; 2) Membandingkan apa yang dikatakan orang di depan umum dengan apa yang dikatakan orang secara pribadi; 3) Membandingkan apa yang dikatakan orang-orang tentang situasi penelitiandengan apa yang dikatakannya sepanjang waktu; 4) Membandingkan keadaan dan perspektif seseorang dengan berbagai pendapat dan pandangan orang seperti rakyat biasa, orang berpendidikan menengah atau tinggi, orang berada, pemerintah; dan 5) Membandingkan hasil wawancara dengan isi suatu dokumen yang berkaitan.

\section{TEMUAN DAN PEMBAHASAN}

\section{Temuan}

Hubungan antar guru maupun antara anak didik dan guru di KB Anggrek Muara Badak Kutai Kartanegara berjalan dengan baik dan komunikatif. Hal ini dapat terlihat pada kegiatan sehari hari dalam pembelajaran dan diluar pembelajaran yang dilaksanakan di sekolah. Begitu pula hubungan antara guru dengan orang tua anak didik juga beijalan dengan baik. Hal ini terlihat dari adanya kegiatan yang selalu melibatkan orang tua siswa dalam pembelajaran anak seperti pendampingan orang tua siswa dalam pembelajaran diluar sekolah. Secara keselururhan interaksi sosial di di KB 
Anggrek Muara Badak Kutai Kartanegara beijalan dengan baik dan komunikatif.

Berdasarkan data observasi di sekolah bahwa kualifikasi pendidikan yang dimiliki oleh guru di KB Anggrek Muara Badak Kutai Kartanegara mayoritas SLTA atau belum memiliki akta IV seehingga dapat dikatakan sekolah ini belum mencapai standarisasi pendidikan.Adapun jumlah guru dan karyawan di KB Anggrek Muara Badak Kutai Kartanegara Tahun Pelajaran 2015/2016 berjumlah 3 orang yaitu 2 orang guru dan 1 tenaga administrasi sekolah.

Kepada kedua orang guru tersebut diberikan pertanyaan meliputi:Perencanaan dalam kegiatan pembelajaran dikelas, Prinsip AUD, Kesesuaian RPPH dengan prinsip AUD, Teknik menata lingkungan bermain dikelas. Juga diberi pertanyaan yang berhubungan dengan emosional anak didik meliputi: kemampuan guru dalam mengenali tanda-tanda anak marah, Jumlah anak yang suka marah, penyebab anak marah, serta kegiatan yang dilakukan untuk mengelola amarah anak dikelas.

Kepada orang tua anak yang sering marah ini diberi pertanyaan mengenai emosional anak mereka meliputi : anak keberapa, berapa jumlah saudara kandung, apakah kecemburuan pada saudara pernah teijadi pada anak anda, apakah disiplin itu penting, bagaimana cara anda mendisiplinkan anak saat dirumah, apakah anak anda pernah protes dengan pola disiplin yang anda terapkan, apakah anda selaku orang tua pernah mendikte anak anda, dimanakah anak biasa bermain ketika dirumah, apakah anak anda sering marah, faktor apa yang menyebabkan anak marah, apakah anak anda pernah merasa kurang diperhatikan saat dirumah, pernahkah beijanji pada anak kemudian tidak menepatinya.

\section{Hasil Wawancara}

Berdasarkan hasil pengambilan data yang telah dilakukan pada hari Senin hingga jumat pada tanggal 1419September 2015, oleh penulis (lampiran), bahwa pengembangan rencana pembelajaran yaitu kegiatan merumuskan tujuan apa yang akan dicapai oleh suatu kegiatan pengajaran, cara apa yang yang dipakai untuk menilai tujuan tersebut, materi bahan apa yang akan disampaikan, bagaimanan cara menyampaikannya serta alat atau media apa yang diperlukan yang disesuaikan dengan tingkat perkembangan anak didik. Berikut ini hasil wawancara dengan guru Kelas :

1. Hasil Wawancara dengan guru :

Guru yang menjadi subjek penelitian ada 2 (dua) orang yang merupakan guru yang mengajar di kelompok $\mathrm{B}$ di $\mathrm{KB}$ Anggrek Muara Badak Kutai Kartanegara Tahun Pelajaran 2015/2016 yaitu: 


\section{a. Ibu Masna}

Kepada Ibu Masna diberikan beberapa pertanyaan sebagai berikut:

1) Bagaimana perencanaan anda dalam kegiatan pembelajaran dikelas ? Jawab : saya memulai perencanaan kegiatan pembelajaran dikelasyaitu dengan pembuatan RPPM dan RPPH. RPPM dan RPPH tersebut disesuaikan dengan perencanaan per semester.

2) Apakah anda memahami prinsip AUD ? Jawab : Sedikit. Sebenarnya saya tidak memiliki dasar dalam teorinya namun dari pengamatan dan pengalaman selama delapan tahun inilah yang saya ketahui dari perkembangan anak, dan saya berusaha untuk meningkatkan kompetensi saya di bangku kuliah, dan sekarang saya sedang menyelesaikan tugas ahir saya untuk program S1.

3) Apakah dalam merencanakan RPPH anda sesuaikan dengan prinsip AUD? Jawab : menurut saya merupakan suatu kewajiban guru dalam menyusun RPPH yang tematik dan sesua prinsip prinsip pembelajaran pada pendidikan anak usia dini.

4) Bagaimana teknik anda dalam menata lingkungan bermain dikelas ? Jawab : Tekniknya ya dengan menciptakan suasana kondusif dalam pembelajaran, memeliharalingkungan yang bersih, aman, nyaman dan sehat bagi anak .

5) Bagaimanakah anda mengenali tanda-tanda anak marah ? Jawab : Mengenali jika ada anak yang berteriak, menangis, menyendiri dan memukul temannya. Berapa banyak

6) anak didik yang suka marah ? Jawab : 3 anak.

7) Saat salah satu anak didik anda marah, apa yang anda lakukan ? Jawab : Mendekati, menanyakan penyebab kemarahannya, membujuk dan menjelaskan bahwa marah tidak baik, serta menasehati untuk selalu bersikap yang baik terhadap temantemannya.

8) Menurut pengamatan anda, faktor apa saja yang membuat anak didik marah ? Jawab : Tidak mampu melakukan sesuatu sesuai kehendak dirinya,diganggu temannya, kelelahan dan berebut mainan.

9) Apakah ada kegiatan yang dapat anda lakukan untuk mengelola amarah anak dikelas ?Jawab : Meminta anak untuk mengutarakan perasaannya,membimbing anak dalam menan amkan tingkah laku yang baik dan mengajarkan anak untuk bersikap sabar dalam suasana kekeluargaan, suasana yang penuh 
kasih sayang,dan mengalihkan perhatian anak, biasanya diajak untuk bermain.

10) Apakah ada kegiatan mengevaluasi amarah anak ? Jawab : Ada, meninjau kembali apakah tindakan yang telah diambil ketika menangani anak yang marah sudah sesuai dengan karakter pendidikan pada anak usia dini dan mengatur tindakan yang akan dilakukan ketika anak marah pada kegiatan berikutnya.

Berdasarkan Jawaban kedua orang guru yang menjadi responden dalam penelitian ini diketahui bahwa kedua orang guru di kelompok $\mathrm{B}$ di $\mathrm{KB}$ Anggrek Muara Badak Kutai Kartanegara Tahun Pelajaran 2015/2016:

1) Sudah mulai memahami perencanaan pembelajaran yang benar.

2) Sudah mulai memahami prinsip AUD

3) Keduanya memahami keadaan anak sedang marah dan sudah mulai mampu membantu anak mengelola amarahnya.

2. Hasil Wawancara dengan Orang Tua Anak

Karena ada 3 (tiga) orang anak yang pemarah maka orang tua yang menjadi respondenpun sebanyak 3 (tiga) orang. Kepada Orang Tua anak Didik yang pemarah diberikan pertanyaan sebagai berikut :

a. Ibu Marlina
1) Apakah anda pernah memberikan sebuah janji kepada anak kemudian anda lupa dan tidak menepatinya ? Jawab : Pernah. Ya, anak saya marah. Kemudian saya bujuk biar tidak marah lagi. Namun beberapa saat kemudian jika ingat lagi, anak saya menagih janji yang pernah saya katakan.

2) Berapa saudara kandung ? Jawab: Dua.

3) Dari anak keberapa putra/putri anda yang bernama A ? Jawab: Anak Pertama.

4) Apakah anak anda pernah merasa kurang diperhatikan saat dirumah? Jawab : Pernah. Biasanya saat saya sedang sibuk masak didapur lalu ketika dia minta ditemani nonton dan saya tidak bisa menemani saat itu sehingga membuatnya ngambek.

5) Apakah menurut anda disiplin itu penting bagi anak anda? Jawab: Penting.

6) Bagaimana cara anda mendisiplinkan anak saat dirumah ? Jawab : Saya mendisiplinkan Sathya dengan mencuci piring sendiri setelah makan dan tidur siang hari.

7) Apakah anak anda pernah protes dengan pola disiplin yang anda terapkan? Jawab: Bukan protes sih menurut saya hanya saja dia terkadangmalas-malasan untuk 
melakukan disiplin yang saya terapkan.

8) Apakah kecemburuan pada saudara pernah terjadi pada anak anda? Jawab : Pernah, namanya juga anak-anak. Kadang ketika sayamembelikan mainan untuk adiknya, dia juga minta dibelikan mainan.

9) Apakah anda selaku orang tua pernah mendikte anak anda? Jawab : Pernah. Seperti saat anak saya sedang makan, kebetulan dia tidak menyukai sayur jadi saya selalu menyuruh Sathya untuk makan sayur.

10) Dimanakah anak biasa bermain ketika dirumah ?Jawab : Ketika dirumah, anak saya bermain diluar bersama teman-temannya.

11) Apakah anak anda sering marah ? Biasanya faktor apa yang menyebabkan anak marah ? Jawab: Sering. Biasanya kalau dia bermain di luar sama temannya, sering kali saya melihat dia menangis. Mungkin karena teman-temannya tidak mau berteman sama Sathya. Ya biasalah anak kecil kadang-kadang begitu.

12) Bagaimana cara mengatasi ketika anak anda marah ? Jawab: Kalau dia nangis saat diluar rumah, ya saya ajak dia masuk rumah. Kemudian berusaha menenangkan sambil menanyakan penyebabnya lalu menasehatinya.
Berdasarkan jawaban dari ketiga responden diketahui bahwa:

1) Anak pemarah karena Kurang perhatian, terlalu didekti, punya saudara yang usianya tidak terpaut jauh hingga terjadi pola asuh yang cendrung memihak kepada salah satu anak.

2) Meski ada anak tunggal yang pemarah tetapi itu terjadi karena pola asuh orang tua yang cenderung terlalu memanjakan anak.

3) anak berubah menjadi pemarah apabila diasuh dengan pola asuh yang salah

\section{Hasil observasi kegiatan pembelajaran}

1. Guru mengorganisasikan amarah anak menjadi pengembangan kecerdasan emosi dengan membujuk anak dengan kasih sayang dan mengembangkan sikap pribadi yang baik. Kegiatan yang diorganisasikan bersifat holistik ( menyeluruh ).diantaranya dikondisikan dalam suasana kekeluargaan, suasana yang penuh kasih sayang, suasana yang penuh kesejukan dan kedamaian, tetapi tetap dapat menempatkan setiap komponen secara bertanggung jawab atas setiap peran yang dipegangnya.

2. Kegiatan diorganisasikan pada suasana yang dapat memberikan kesempatan kepada anak untuk menyampaikan alasan alasan mengapa marah, 
kemudian guru membimbing dan memfasilitasi bukan untuk mengatur berbagai prilaku secara otoriter tetapi memberikan kesempatan pada anak untuk saling bermaafan.

3. Guru mengarahkan anak untuk mentaati tata tertib sekolah secara utuh dan bertanggung jawab.

4. Pembimbingan dan kegiatan memfasilitasi dilakukan dengan penuh kasih sayang sehingga dapat mempersiapkan anak menjadi pribadi dan anggota masyarakat yang sehat dan mampu bersosialisasi dan berkomunikasi.

5. Guru juga memberikan kesempatan dan menganjurkan agar orang tua dapat berpartisipasi dalam mengendalikan amarah anak-anaknya dalam kegiatan dirumah.

\section{Pembahasan}

Hasil observasi dan wawancara terhadap guru dan orang tua anak didik, diketahui bahwa anak didik yang suka marah biasanya disebabkan berebut mainan, diganggu temannya, adanya larangan dan ketidakmampuan membendung emosi. Hal demikian menuntut kemampuan orang tua dan guru untuk mampu mengenali dan mengelola amarah anak tersebut. Berdasarkan data dan hasil wawancara dengan guru diketahui kemampuan guru dalam penentuan strategi pembelajaran turut andil terhadap kemampuan anak mengelola amarahnya. Sebagaimana halnya sebuah TK dalam memulai kegiatan pembelajaran diawali dengan merancang program semester, rencana pelaksanaan pembelajaran mingguan (RPPM) dan rencana pelaksanaan pembelajaran harian (RPPH). Strategi pembelajaran yang digunakan guru dalam kegiatan pembelajaran dimulai dengan pembuatan rencana pelaksanaan pembelajaran harian (RPPH). Selanjutnya didalam pelaksanaan kegiatan pembelajarannya kurang menarik perhatian anak didik hal ini disebabkan karena guru tersebut mulai memahami prinsip-prinsip perkembangan anak didik didalam merancang rencana pelaksanaan pembelajaran harian (RPPH). Didalam teknik menata lingkungan bermain dikelas kedua guru sudah dapat menyediakan bahan-bahan, media pembelajaran yang akan digunakan serta mampu menciptakan dan memelihara lingkungan yang aman dan sehat bagi anak.

Berdasarkan hasi wawancara langsung dengan orang tua wali dapat disimpulkan bahwa; (1) Anak pemarah karena Kurang perhatian, terlalu didekti, punya saudara yang usianya tidak terpaut jauh hingga terjadi pola asuh yang cendrung memihak kepada salah satu anak. (2) Meski ada anak tunggal yang pemarah tetapi itu terjadi karena pola asuh orang tua yang 
cenderung terlalu memanjakan anak, dan (3) Anak berubah menjadi pemarah apabila diasuh dengan pola asuh yang salah.

Menghadapi anak yang sedang marah saat pembelajaran, guru di KB Anggrek Muara Badak sudah mulai mampu menciptakan atau mengkreatifitaskan keterampilan mengajar mereka dengan maksimal. Ini tampak pada proses pembelajaran yang variatif sehingga amarah anak dapat diatasi dengan baik namun beberapa anak kelihatan jenuh dan beralih mengganggu temannya dan suasana kelas pun menjadi kurang tertib. Karena kemampuan guru dalam membimbing anak dan mengelola emosinya anakpun berubah menjadi lebih sabar sehingga pembelajaran menjadi kodusif . Dalam proses pembelaran di kelompok B KB Anggrek Muara Badak Kutai Kartanegara Tahun Pelajaran 2015/2016 adalah sebagai berikut :

1. Guru mengorganisasikan amarah anak menjadi pengembangan kecerdasan emosi dengan membujuk anak dengan kasih sayang dan mengembangkan sikap pribadi yang baik. Kegiatan yang diorganisasikan bersifat holistik ( menyeluruh ).diantaranya dikondisikan dalam suasana kekeluargaan, suasana yang penuh kasih sayang, suasana yang penuh kesejukan dan kedamaian, tetapi tetap dapat menempatkan setiap komponen secara bertanggung jawab atas setiap peran yang dipegangnya.

2. Kegiatan diorganisasikan pada suasana yang dapat memberikan kesempatan kepada anak untuk menyampaikan alasan alasan mengapa marah, kemudian guru membimbing dan memfasilitasi bukan untuk mengatur berbagai prilaku secara otoriter tetapi memberikan kesempatan pada anak untuk saling bermaafan.

3. Guru mengarahkan anak untuk mentaati tata tertib sekolah secara utuh dan bertanggung jawab.

4. Pembimbingan dan kegiatan memfasilitasi dilakukan dengan penuh kasih sayang sehingga dapat mempersiapkan anak menjadi pribadi dan anggota masyarakat yang sehat dan mampu bersosialisasi dan berkomunikasi.

5. Guru juga memberikan kesempatan dan menganjurkan agar orang tua dapat berpartisipasi dalam mengendalikan amarah anak-anaknya dalam kegiatan dirumah.

Hasil tersebut telah mencerminkan strategi yang mengacu pada Tiga unsur penting kecerdasan emosional menurut Kemendikbud (2014: 1) yang terdiri dari: 1) Kecakapan pribadi (mengelola diri 
sendiri), 2) kecakapan sosial (menangani suatu hubungan), 3) keterampilan sosial (kepandaian menggugah tanggapan yang dikehendaki pada orang lain).

Latar belakang pendidikan yang dimiliki guru di KB Anggrek Muara Badak berbanding lurus dengan kondisi anak didik mereka. Terbukti beberapa anak yang pemarah berubah secara perlahan lahan menjadi lebih baik karena kemampuan guru dalam membantu anak mengelola emosi atau amarah mereka.

Terbatasnya pemahaman guru tentang tumbuh kembang anak AUD dan terbatasnya pemahaman guru tentang strategi pembelajaran pada anak AUD ini mengakibatkan anak pemarah tetap jadi anak pemarah atau tidak berubah menjadi lebih baik secara spontan. Mereka dapat diatasi dengan kemampuan guru membimbing anak dengan suasana kekeluargaan dan kasih sayang

Berdasarkan kondisi yang terjadi di di KB Anggrek Muara Badak Tahun Pembelajaran 2015/2016, Strategi Pembelajaran Guru dalam Mengelola Amarah Siswa dengan mengacu pada tiga unsur penting kecerdasan emosional; (1) Kecakapan pribadi (mengelola diri sendiri); (2) kecakapan sosial (menangani suatu hubungan); (3)keterampilan sosial (kepandaian menggugah tanggapan yang dikehendaki pada orang lain). Dari hasil penelitian ini,peneliti mengharapkan didalam pembelajaran memperhatikan halhal sebagai berikut :

1. Pembelajaran yang diterapkan berorientasi pada pembelajaran menurut prinsip-prinsip Perkembangan Anak.

2. Dasar pemikiran pembelajaran yang berorientasi pada konsep dasar strategi belajar mengajar.

\section{KESIMPULAN}

1. Strategi Pembelajaran Guru dalam Mengelola Amarah Siswa pada Pada Kelompok B di KB Anggrek Muara Badak tahun Pembelajaran 2015/2016 mengacu pada tiga unsur penting kecerdasan emosional;

Kecakapan pribadi (mengelola diri sendiri); (2) kecakapan sosial (menangani suatu hubungan); (3)keterampilan sosial (kepandaian menggugah tanggapan yang dikehendaki pada orang lain).

2. Penyebab anak didik menjadi pemarah adalah : (1) karena Kurang perhatian, terlalu didekti, punya saudara yang usianya tidak terpaut jauh hingga terjadi pola asuh yang cendrung memihak kepada salah satu anak. (2) Meski ada anak tunggal yang pemarah tetapi itu terjadi karena pola asuh orang tua yang cenderung terlalu memanjakan anak

6. Kemampuan guru dalam memberikan pembelajaran juga sangat 
berpengaruh terhadap kemampuan anak mengelola emosi atau amarah mereka. Pemilihan strategi pembelajaran yang tepat membantu anak mengelola emosi atau amarah mereka sebaliknya kesalahan strategi yang guru terapkan dapat membuat anak tambah pemarah. Guru yang berkualitas cerdas dalam menentukan strategi pembelajaran, mengerti , tumbuh kembang anak dan dapat mengenali emosi anak sehingga mampu membantu anak mengelola amarahnya.

\section{SARAN}

1. Penerapan berbagai strategi pembelajaran dalam Mengelola Amarah Siswa hendaknya mengacu pada tiga unsur kecerdasan emosional.

2. Dalam mengelola amarah siswa, pembelajaran yang diterapkan diharapkan berorientasi pada pembelajaran menurut prinsip-prinsip Perkembangan Anak.

3. Bagi KB Anggrek Muara Badak, diharapkan lebih meningkatkankan kualifikasinya yang salah satunya dengan menambah jumlah guru yang berlatar belakang pendidikan PAUD sehingga KB Anggrek Muara Badak ini bisa menjadi media perantara dalam pemberian informasi tentang perkembangan anak, khusunya perkembangan kecerdasan emosional.

4. Bagi orang tua, sebagai pendidik pertama dan utama dalam perkembangan anak khususnya perkembangan emosional anak, diharapkan orang tua memperhatikan dan berperan lebih aktif dalam mengembangkan emosional anak. Terutama bagi orang tua yang kurang memiliki pengalaman, diharapkan tidak enggan untuk menambah ilmunya tentang perkembangan anak usia dini.

\section{DAFTAR PUSTAKA}

Arikunto, Suharsimi. 2010.

ProsedurPenelitian. Jakarta : Rineka Cipta.

Hurlock, Elizabet. 1992. Perkembangan Anak. Jakarta. PT. Erlangga.

Dharma,Surya,.M.Pd.,Ph.D. 2008.Strategi Pembelajaran. Direktur Tenaga Kependidikan,Ditjen PMPTK .Jakarta.

Hadi, Amirul dan H. Haryono. 2005. Metodologi Penelitian Pendidikan.Bandung: PT. Pustaka Setia.

http://dachun91 .wordpress.com/2010/11/22/karakt eristik-anak-usia-dini/) diakses bulan September2015

http://novaoktriyani.blogspot.com/2012/12 /karakteristik-perkembangananak-usia.html diakses bulan September2015 
Lexy J.Moleong,2010 .Metodologi

Penelitian Kualitatif, (Bandung,:

Remaja Rosdakarya,

Margono, S.Metodologi Penelitian Pendidikan. PT: Rineka Cipta

Masitoh,dkk. 2007. Strategi Pembelajaran TK. Jakarta. PT : Universitas Terbuka

Mulyadi, Seto. 2004. Membantu anak Balita Mengelola Amarahnya. PT : Erlangga

Pusat Bahasa Departemen Pendidikan Nasional. 2007. Kamus Besar Bahasa Indonesia. Jakarta : Balai Pustaka

P. Joko Subagyo, 1997 .Metode Penelitian Dalam Teori dan Praktek. Jakarta : Rineka Cipta.

Sanjaya, Wina. 2008. Strategi Pembelajaran. Jakarta: Media Prenada

Sanjaya, Wina. 2010. Strategi Pembelajaran Berorientasi Standar Proses Pendidikan. Jakarta. PT : Kencana.

Syaiful Bahri Djamarah dan Aswan Zain, . Strategi Belajar Mengajar, (Jakarta:Rineka Cipta,), Ct. ke-1,
Sugiyono. 2010 .Metode Penelitian Kuantitatif Kualitatif dan $R \& D$. Bandung. PT: CV. Alfabeta.

Supardi. 2006. Penelitian Tindakan Kelas. Jakarta. PT : Bumi Aksara

Tandry, Novita. 2011. Buku Pintar Perilaku Anak. PT. Libri.

Tim Pengembang PAUDKementerian Pendidikan dan Kebudayaan, Direktorak Jenderal Pendidikan Anak Usia Dini Nonformal dan Informal.2014. Pengembangan Kecerdasan Sosial Emosional Anak. Pusat Pengembangan Pendidikan Anak Usia Dini Non formal dan Informal (PPPAUDNI) Regional II Semarang.

Tim Prima Pena, . Kamus Besar Bahasa Indonesia, Gitamedia Press,

Uno, B. Hamzah. 2006. Perencanaan Pembelajaran. Jakarta: Bumi Aksara.

Yamin, Martinis. 2006. Strategi Pembelajaran Berbasis Kompetensi. Jakarta: Gaung Persada Press.

Yin, Robert K. 1996. Studi Kasus (Desain \& Metode). PT. Raja Gravindo Persada 
